\title{
Strategi Komunikasi Politik dan Budaya Transparansi Partai Politik
}

\author{
ATIE RACHMIATIE, ${ }^{1}$ O. HASBIANSYAH, ${ }^{2}$ EMA KHOTIMAH, ${ }^{3}$ DADI AHMADI ${ }^{4}$ \\ Fakultas IImu Komunikasi, Unisba, Jl. Tamansari No.1 Bandung 40116 \\ email: ${ }^{1}$ atierachmiatie@yahoo.com, 2 hasbiansyah@yahoo.com, ${ }^{3}$ dadi.ahmadi@gmail.com
}

\begin{abstract}
Freedom of information has become a momentum for the effort to realize "good governance" and promote democratic governance system in Indonesia. With the enactment of Freedom of Information Law No. 14 of 2008, the public was given access to the right of public information as human right such as guaranteed by law. Public freedom of information should encourage public participation. Political parties as public institutions also have to give information in the service of the public who wish to access any kind of information which is regulated by law. However, based on reports ICW, how difficult political parties provide the information requested by the ICW. This paper examines the political culture, political communication strategies and public freedom of information within the political parties.
\end{abstract}

Keywords: communications politic, transparantion of information, political parties

\begin{abstract}
Abstrak. Keterbukaan informasi telah menjadi momentum bagi upaya merealisasikan "good governance" dan mendorong sistem pemerintahan yang demokratis di Indonesia. Dengan berlakunya UU KIP no 14 tahun 2008, masyarakat diberi akses dan hak atas informasi publik yang merupakan hak asasi manusia serta dijamin oleh undang-undang. Selain itu, keterbukaan informasi publik seharusnya mendorong partisipasi publik. Partai politik sebagai lembaga publik, tidak terkecuali dituntut melakukan pelayanan informasi terhadap publik yang ingin mengakses segala jenis informasi yang diatur oleh undang-undang. Namun, berdasarkan laporan ICW, betapa sulitnya partai politik memberikan informasi yang diminta oleh pihak ICW. Artikel ini menelaah budaya politik, strategi komunikasi politik dan keterbukaan informasi publik di lingkungan partai politik.
\end{abstract}

Kata kunci: Komunikasi Politik, Transparansi informasi, Partai Politik

\section{Pendahuluan}

Partai Politik saat ini mengisyaratkan ada persoalan mendasar walaupun secara de jure (hukum) tidak nampak, yaitu secara sosiologispolitis adanya ketertutupan partai politik dalam pengelolaan/manajemen secara kelembagaannya, seperti tidak transparannya ketika rekruitmen anggota, berhembusnya "Money Politic" ketika mengkaderkan anggotanya sebagai pejabat politik, suara pemilih yang bisa dibeli, rendahnya kualitas anggota yang terpilih dalam parlemen, tidak jelasnya ideologi atau platform yang diperjuangkan dan banyak faktor yang tidak dipahami oleh masyarakat tentang "seluk beluk" partai politik yang menyebabkan rendahnya pula kualitas politik dalam kehidupan berbangsa dan bernegara.

Di sisi lain kita sudah memiliki Undangundang tentang Keterbukaan Informasi Publik (KIP) nomor $14 / 2008$ yang mewajibkan partai politik harus transparan sebagai badan publik yang menerima sebagian atau seluruh anggarannya dari negara (APBN/APBD). Namun adanya undangundang tersebut, tidak membuat partai politik lebih terbuka kepada masyarakat tentang informasi yang terkait dengan kelembagaannya. Disamping, tidak berjalannya relasi antara partai politik dengan para konstituennya secara memadai baik dari segi kuantitas maupun kualitas. Umumnya komunikasi politik yang dijalankan partai politik saat ini banyak yang bersifat "hit \& run", hanya berlangsung sesaat, sporadis dan bahkan ada yang nyaris berlangsung pada saat pemilihan Umum saja.

Program pembangunan yang selama ini ditujukan bagi partai politik belum dapat melepaskan dari independensi, perjuangan untuk rakyat, konsistensi dengan platform yang dimiliki. Umumnya Partai politik saat ini bekerja memiliki beban lebih berat, karena tuntutan masyarakat yang lebih tinggi, persaingan yang tidak sehat antar 
partai politik serta orientasi sistem politik yang belum mapan. Studi-studi terhadap partai politik dalam pembangunan sistem politik yang lebih sehat mengisyaratkan persoalan mendasar, yaitu: Pertama, dari sisi normatif tidak ada persoalan menyangkut peran partai politik. Negara dan Pemerintah telah memandang peran dan kedudukan partai politik sebagai hal yang perlu mendapat perhatian serius dari semua pihak.

Kedua, adanya persoalan sosiologis-politis di masyarakat. Persoalan partai politik yang terkait sosiologis-politis amat kompleks, diantaranya adanya kepentingan pragmatis partai politik, yang hanya berorientasi pada kekuasaan dan finansial, kualitas/kompetensi pengurus partai politik yang rendah, atau bukan "negarawan" sejati, tingkat kemandirian lembaga partai politik yang rendah, serta peran dan kedudukan partai politik yang rendah dalam sosialisasi, komunikasi dan pendidikan politik menuju kehidupan berbangsa dan bernegara yang lebih berkualitas. Ketiga, Pemerintah telah menggariskan kebijakan kerja sama dengan lembaga nonpemerintah dalam upaya peningkatan kualitas partai politik di Indonesia. Kebijakan ini merupakan salah satu indikator proses desentralisasi kekuasaan dan program peningkatan kualitas sumber daya manusia. Atau dengan kata lain, pemerintah memberikan ruang partisipasi yang luas terhadap masyarakat dalam memecahkan masalah partai politik Indonesia secara kolektif.

Keempat, terdapat asumsi kolektif bahwa peningkatan kualitas partai politik akan memberikan pengaruh yang signifikan terhadap peningkatan kualitas berbangsa dan bernegara bagi masyarakat.

Hal ini didukung juga hasil penelitian dari Rachmiatie dalam Mimbar Volume XXI No. 2 April Juni 2005, hal 178-195, lebih dari setengahnya $(51,03 \%)$ responden memerlukan informasi untuk pengetahuan dalam kehidupan bernegara tentang HAM, Hak \& Kewajiban WNI/WNA, Sebagian Kecil $(30,59 \%)$ memerlukan informasi untuk pengetahuan dalam kehidupan bernegara tentang Kewajiban Pemerintah/ Pemimpin Kepada Rakyat, dan $(18,38 \%)$ memerlukan informasi untuk pengetahuan dalam kehidupan bernegara tentang Hukum, Demokrasi. Data penelitian di atas menunjukkan bahwa informasi yang dibutuhkan responden terpenting adalah hak dan kewajibannya sebagai warga negara serta kedua terpenting adalah kewajiban pemerintah/ Pemimpin pada rakyatnya.

Menurut laporan Indonesia Corruption Watch (ICW) (November 2013), salah satu penyebab dari buruknya kualitas demokrasi di Indonesia adalah tiadanya transparansi dalam pengelolaan keuangan partai politik maupun dana kampanyenya. Banyak kasus korupsi yang terungkap menunjukkan bahwa dana dari kejahatan itu digunakan untuk kepentingan pemenangan pemilu, baik di tingkat nasional maupun lokal. Untuk mendorong semakin baiknya tata kelola keuangan partai politik, ICW berinisiatif meminta informasi keuangan partai politik dengan dasar UU No 14 Tahun 2008, tentang Keterbukaan Informasi Publik.

Sebagian besar partai politik tidak mau menyerahkan laporan keuangan dan program kerja yang diminta. Hanya tiga partai politik yaitu PKS, Partai Hanura, dan Partai Gerindra yang merespon dengan menyerahkan Laporan Keuangan. PKS memberikan laporan keuangan tahun 2010. Gerindra menyerahkan laporan keuangan dari APBN tahun 2011 dan surat konfirmasi masih dalam proses audit untuk laporan keuangan. Hanura memberikan laporan keuangan dari APBN tahun 2011. Padahal permintaan tersebut berdasarkan pada UU KIP Pasal 15 huruf (b) dimana partai politik wajib menyediakan informasi publik berupa program umum dan kegiatan partai politik. Selain itu, permintaan informasi telah sesuai dengan Pasal 39 ayat (3) UU No. 2 tahun 2011, tentang Partai Politik yang menyebutkan bahwa Partai Politik wajib membuat laporan keuangan dan terbuka untuk diketahui masyarakat.

Partai Politik di daerah menurut laporan ICW tidak ada bedanya dengan kantor pusatnya, partai politik di daerah juga banyak yang enggan memberikan laporan keuangan dan program kerja mereka. Bahkan yang lebih buruk, ada beberapa partai politik yang tidak memiliki laporan keuangan sama sekali. Tentu hal ini menunjukkan bahwa tata kelola partai politik di Indonesia sangat buruk. Bisa dikatakan, pengurus partai politik tidak menjalankan kewajibannya untuk mencatat semua penerimaan dan pengeluaran dana yang diterima. Gambaran ini kian mempertegas asumsi bahwa keuangan partai politik berasal dari sumber yang tidak dapat dipertanggungjawabkan kepada publik.

Penolakan sebagian partai politik atas keterbukaan informasi publik tentu bertolakbelakang dengan komitmen mewujudkan transparansi dan akuntabilitas partai. Padahal selama ini, semua partai politik secara lisan mendukung transparansi dan antikorupsi. Di samping itu, partai politik seharusnya bersikap terbuka karena sumber dana yang mereka gunakan berasal dari publik dan pada sisi yang lain, partai politik kini tengah meminta kenaikan subsidi dari negara. Hingga saat ini, ICW dengan KIP sebagai mediator, sedang terus berkomunikasi dengan partai politik untuk meyakinkan pentingnya keterbukaan informasi publik. Harapannya, ada perubahan yang -meskipun secara bertahap- lebih baik dalam tata kelola keuangan partai politik di Indonesia. 
Artikel ini merupakan penelitian kualitatif dengan metode deskriptif analitik. Data primer dikumpulkan melalui guide interview, in-dept interview, dan retrospective. Data yang terkumpul kemudian dianalisis dengan menggunakan parameter budaya politik dan keterbukaan informasi publik.

\section{Budaya Politik}

"Budaya adalah komunikasi dan komunikasi adalah budaya" merupakan idiom dari pakar antropologi yang bermakna luas dan mendalam. Artinya, budaya tidak bisa tercipta tanpa adanya komunikasi dalam suatu masyarakat dan sebaliknya komunikasi tidak akan ada tanpa kehidupan budaya didalamnya. Budaya politik dan sosialisasi politik merupakan pendekatan ilmu politik, ilmu komunikasi dan antropologi dalam membaca fenomena ini. Penelitian dari Amerika Serikat yang dilaksanakan Gabriel A. Almond dan Sydney Verba yang dituangkan dalam buku "Political Culture", merupakan hasil kajian antara tahun 1969 sampai dengan 1970 atas 5000 responden yang tersebar di 5 negara: Amerika Serikat, Inggris, I talia, Meksiko, dan J erman Barat. Hasil penelitian tersebut mengemukakan bahwa Budaya politik berarti kecenderungan berperilaku individu terhadap sistem politik yang berlaku di negaranya. Dalam pendekatan budaya politik, individu merupakan subjek kajian yang utama dan bersifat empiris, jadi diambil dari pendapat orang per orang. Adapun pendekatan filsafat politik, bersifat lebih abstrak karena pendapat dibangun oleh seseorang tanpa terlebih dahulu melihat fakta lapangan, atau paling tidak, melalui serangkaian penelitian yang melibatkan orang banyak. Budaya politik adalah cara individu berpikir, merasa, dan bertindak terhadap sistem politik serta bagian-bagian yang ada di dalamnya, termasuk sikap atas peranan mereka sendiri di dalam sistem politik.

Orientasi/ kecenderungan individu terhadap sistem politik menurut Tumija Adipawira Word press, (diunduh 28 juli 2013) terbagi tiga bagian, yaitu: Orientasi Kognitif, Afektif, dan Evaluatif.

Orientasi kognitif adalah pengetahuan. Bagaimana individu mengetahui hak dan kewajiban warga negara di dalam konstitusi, bagaimana individu mengetahui tata cara pemilihan umum, bagaimana individu mengetahui partai politik dan aktivitas partai tersebut, bagaimana individu mengetahui perilaku pemimpin-pemimpin mereka lewat pemberitaan massa, merupakan contoh dari orientasi kognitif ini. Pengetahuan-pengetahuan ini bersifat tidak tetap. Pengetahuan bertambah atau tetap seiring dengan pengaruh-pengaruh dari lingkungan sekeliling individu.

Orientasi afektif berbeda dengan orientasi kognitif, oleh sebab orientasi afektif ini bergerak di dalam konteks perasaan. Perasaan-perasaan seperti diperhatikan, diuntungkan, merasa adil, sejahtera, suka atau tidak suka, ataupun sejenisnya, kerap lebih menentukan ketimbang faktor pengetahuan. Oleh sebab itu, banyak pemimpin negara yang mengeluarkan kebijakankebijakan populis (sifatnya populer) untuk mendongkrak aspek afektif warga negara. Di Indonesia, kebijakan-kebijakan seperti Bantuan Langsung Tunai, Askeskin, Pembagian Kompor Gas, dan sejenisnya bertujuan untuk mengubah orientasi afektif warga negaranya. Tujuan akhirnya adalah, agar masyarakat merasa diperhatikan oleh pimpinan politik, dan mereka akan memilih para pemberi bantuan di kemudian hari.

Orientasi Evaluatif merupakan campuran antara orientasi kognitif dan afektif di dalam bentuk keputusan/tindakan. Misalnya, setelah mengetahui bahwa partai A atau B memang benar menyuarakan apa yang mereka inginkan, individu memilih mereka di dalam suatu pemilu. Kasus lain jika sekelompok individu menggelar unjuk rasa untuk mendukung seorang calon yang tengah 'diserang' oleh lawan politiknya, semata-mata karena mereka merasa kenal dan sedikit tahu akan jatidiri si politisi termaksud. Orientasi Evalutif muncul akibat adanya pengaruh dari orientasi kognitif dan afektif.

\section{Strategi Komunikasi Politik}

Strategi komunikasi merupakan suatu konsep yang banyak diadopsi dari berbagai ilmu ekonomi, politik atau biasa ditemukan pada istilah militer dalam peperangan, namun kata "strategi" merujuk pada seperangkat komponen atau unsur dalam komunikasi yang sangat spesifik berdasarkan konteks yang dihadapi untuk mencapai keberhasilan atau efektifitas komunikasi. Hamijoyo (1999) menyebutkan bahwa dalam strategi komunikasi akan ada perencanaan, taktik, pengenalan lapangan (fact finding), perhitungan lingkungan/ekologi komunikasi, pelaksanaan sampai pada target sasaran. Dengan demikian strategi komunikasi dalam satu konteks atau sebuah situasi, tidak akan persis sama dapat diterapkan dalam konteks lain. Namun demikian peran dan fungsi strategi komunikasi dalam sebuah lembaga atau aktivitas komunikasi sangat penting untuk mencapai tujuan yang diharapkan. Secara umum Thompson (2001) menggambarkan unsur strategi komunikasi sebagai berikut: Pertama, visi organisasi atau perspektif harus dimiliki dan dijadikan acuan dalam mengatur lebih lanjut aktivitas komunikasi. Kedua, menetapkan serangkaian rencana yang diturunkan dari visi dan misi, perencanaan yang tepat juga berangkat dari serangkaian data dan informasi yang ditemukan 
di lapangan (fact finding). Ketiga, menetapkan taktik, yaitu langkah-langkah praktis yang harus ditempuh, dengan sudah memertimbangkan kemampuan internal serta situasi atau keadaan lapangan. Keempat, meletakkan posisi atau kedudukan organisasi maupun program komunikasi dalam konteks lingkungan yang dihadapi, termasuk menempatkan berbagai komponen komunikasi seperti komunikator, sumber, pesan serta target sasaran; Kelima adalah menyusun pola aktivitas komunikasi, sehingga strategi menjadi jelas dan dapat diikuti atau dijalankan oleh semua pelaku komunikasi. Kelima unsur dijelaskan pada Gambar 1.

Strategi komunikasi politik yang terkait dengan partisipasi partai politik secara spesifik sukar ditentukan, oleh karena itu, keberagaman kondisi internal dan lingkungan budaya setempat. Dalam perspektif komunikasi persuasif, Applbaum \& Anatol (1974: 155), strategi komunikasi berarti mempertimbangkan a specific environmental setting; yaitu, hubungan kaum wanita dengan lingkungannya dalam konteks politik yang spesifik, seperti dalam rekrutmen keanggotaan atau pemimpin dalam partai, kampanye, negosiasi, rapat sehari-hari, sidang parlemen, temu konstituen dan aktivitas lainnya. Dalam proses komunikasi ini, semua transmisi informasi politik antara kaum partai politik sebagai sumber atau komunikator dan sebaliknya sebagai penerima; menggunakan pesan verbal dan non verbal, tidak lepas dari frame of reference dan field of experience-nya. Untuk itu pengorganisasian, isi pesan, perangkaian bahasa dan penampilan simbol yang akan disampaikan, harus memertimbangkan efek yang bakal dihasilkan. Sebagai komunikator, kaum partai politik harus selektif mentransmisikan atau menolak sebuah pesan, mengulang-ulang atau meringkas pesan dalam rangka mengambil keputusan yang tepat bagi lawan bicaranya.

Strategi komunikasi ini pun memertimbangkan semua elemen komunikasi yang berkaitan, seperti dikemukakan lebih lanjut oleh Applbaum \& Anatol terdapat beragam model interrelationship yang tergantung bagaimana situasi hubungan timbalbalik antara unsur-unsur yang ada pada peristiwa komunikasi tersebut. Hubungan komponen komunikasi itu diantaranya: (1) The source-receiver relationship yaitu hubungan yang ditentukan oleh tujuan dari aktivitas komunikasi; (2) The source-environment relationship, merujuk pada efek sosial, politik dan budaya pada narasumber dalam situasi komunikasi tertentu; (3) The receiver-environment relationship, merujuk pada efek sosial, politik dan budaya pada seperangkat kondisi psikologis pada penerima; (4) The receiver-message relationship, merujuk pada efek komunikasi yang muncul pada penerima yang disebabkan oleh bentuk, isi dan penyajian pesan. Dengan demikian, elemen utama untuk menetapkan strategi komunikasi politik yang efektif dan efisien, sangat tergantung pada situasi dan lingkungan ketika komunikasi politik tersebut berlangsung. Hal ini akan ditentukan oleh polapola hubungan diantara para pelaku politik yang terlibat didalamnya.

Menurut Sobur dalam Mimbar (2000: 118) bahwa komunikasi politik, sebagai layaknya darah, mengalirkan pesan-pesan politik berupa tuntutan, protes, dan dukungan (aspirasi dan kepentingan) ke jantung (pusat) pemrosesan sistem politik; dan hasil pemerosesan itu, yang tersimpul dalam fungsi-fungsi out-put, dialirkan kembali oleh komunikasi politik yang selanjutnya menjadi feedback sistem politik. Begitulah, komunikasi politik menjadikan sistem politik itu hidup dan dinamis.

Informasi merupakan salah satu bagian yang sangat penting bagi kehidupan masyarakat di dunia saat ini, terlebih jika kita tinggal dalam suatu negara demokrasi yang mengenal adanya pengakuan terhadap kebebasan dalam memeroleh informasi bagi rakyatnya. Tertutupnya kebebasan dalam memeroleh informasi dapat berdampak pada banyak hal, seperti rendahnya tingkat pengetahuan dan wawasan warga negara yang pada akhirnya juga berdampak pada rendahnya kualitas hidup suatu bangsa. Sementara itu, dari segi penyelenggaraan pemerintahan, tidak adanya informasi yang dapat diakses oleh publik dapat berakibat pada lahirnya pemerintahan yang otoriter dan tidak demokratis.

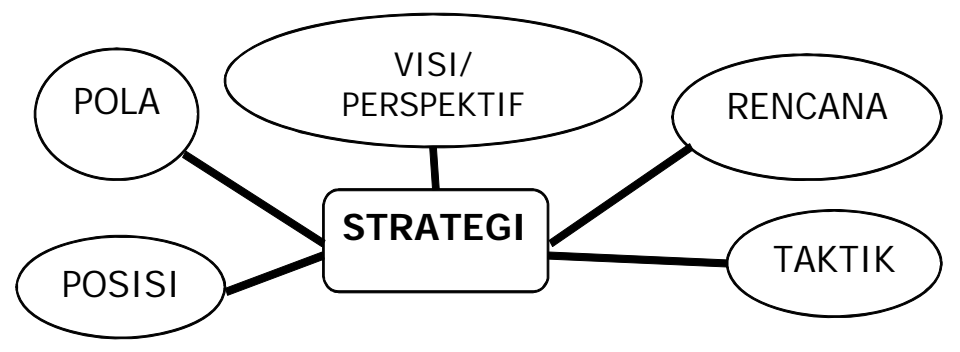

Gambar 1 Unsur Strategi Komunikasi Politik

Sumber: Thompson (2001) "Five views of strategy" 


\section{Transparansi atau Keterbukaan dan Hak Informasi}

UU Keterbukaan Informasi Publik nomor 14/ 2008 adalah peraturan perundangan yang merespon tuntutan reformasi dalam membentuk pemerintahan yang efektif atau good and clean goverment. Secara komprehensif UU KIP telah mengatur kewajiban lembaga publik untuk memberikan akses informasi terbuka dan efisien kepada publik. Jadi, semua lembaga pelayanan publik diajak untuk semakin transparan, dan informasi harus dibuka sebesar-besarnya dengan pengecualian hal-hal yang menyangkut keamanan negara, hak privat dan yang ditur oleh undangundang. Karena pada dasarnya UU KIP memunyai tiga sumbu utama, yaitu: Transparansi, Partisipasi dan Akuntabilitas publik.

Pada dasarnya, pemerintahan di negaranegara demokrasi telah menyadari bahwa terciptanya keterbukaan dalam memeroleh informasi bagi publik dapat memberikan dampak positif bagi kehidupan sosial, politik, ekonomi, dan hukum di negaranya. Keterbukaan informasi dalam penyelenggaraan pemerintahan juga merupakan salah satu wujud komitmen pemerintah dalam melaksanakan prinsip-prinsip good governance dan demokratisasi pemerintahan, di mana salah satu butir di antara butir-butir good governance adalah adanya keterbukaan pemerintah (transparency) kepada masyarakat.

Keterbukaan akses informasi bagi publik di sisi lain juga dapat menjadi salah satu alat penunjang kontrol masyarakat atas kinerja pemerintah ataupun unit-unit kerjanya. Dalam konteks bidang keamanan dan pertahanan, setiap negara demokrasi juga membuka ruang-ruang tersedianya informasi yang dapat diakses masyarakat. Hal ini dimaksudkan agar hak-hak warga negara tetap terjaga dan tidak terenggut. Di samping itu, adanya keterbukaan memeroleh informasi juga dapat menjadikan aktor pertahanan menjadi lebih profesional selalu bertindak dengan berdasarkan hukum.

Konstitusi (UUD) pada hakikatnya merupakan kontrak sosial dalam kehidupan bernegara. Pasal $28 \mathrm{~F}$ pada prinsipnya memberikan hak pada setiap orang untuk berkomunikasi dan memeroleh informasi. Hak tersebut selain diatur dalam pasal tersebut, juga jauh sebelumnya sudah ditetapkan PBB melalui resolusi 59 ayat 1 Tahun 1946 dan International Cevenant on Civil and Political Rights 1966 Deklarasi Universal Hak Asasi Manusia PBB pasal 19, yang menegaskan bahwa hak atas informasi merupakan hak asasi dan hak konstitusional sehingga wajib dilindungi oleh negara. Hak atas informasi tersebut meliputi: (1) Hak publik untuk memantau atau mengamati perilaku pejabat publik dalam menjalankan fungsi publiknya (right to observe); (2) Hak publik untuk mendapatkan/mengakses informasi (public access to information); (3) Hak publik untuk berpartisipasi dalam proses pembentukan kebijakan (right to participate); (4) Kebebasan berekspresi yang salah satunya diwujudkan kebebasan pers (free and responsible pers); (5) Hak publik untuk mengajukan keberatan apabila hak-hak di atas diabaikan (right to appeal) baik melalui administrasi maupun adjudikasi (menggunakan sarana pengadilan semu, arbitrasi maupun pengadilan).

Selain itu, keterbukaan informasi memberi peluang rakyat untuk berpartisipasi dalam berbagai kebijakan publik. Rakyat yang well-informed akan menjadi kekuatan dan aktor dalam proses penentuan dan pengawasan kebijakan publik. Hak itu didasarkan pada pemikiran dan Pengalaman empirik bahwa: (1) Publik yang lebih banyak mendapat informasi dapat berpartisipasi lebih baik dalam proses demokrasi; (2) Parlemen, pers dan publik harus dapat dengan wajar mengikuti dan meneliti tindakan-tindakan pemerintah; kerahasiaan adalah hambatan terbesar pada pertanggungjawaban pemerintah; (3) Pegawai pemerintahan mengambil keputusan-keputusan penting yang berdampak pada kepentingan publik; dan agar bertanggung jawab pemerintah harus menyediakan informasi yang lengkap mengenai apa yang dikerjakan; (4) Arus informasi yang lebih baik menghasilkan pemerintahan yang efektif dan membantu pengembangan yang lebih fleksibel; (5) Kerjasama antara publik dan pemerintah akan semakin erat karena informasi yang semakin banyak tersedia.

\section{Kategorisasi Strategi Komunikasi Politik}

Pada dasarnya UU KIP mempunyai tiga sumbu utama, yaitu: Transparansi, Partisipasi dan Akuntabilitas publik. Partai politik dalam hal ini merupakan lembaga publik yang penting terkait implementasi UU KIP.

Secara hakikat, dari semua unsur Partai Politik memahami tentang hak publik untuk memeroleh informasi seluas-luasnya dari partai politik, baik dari segi program, sistem rekruitmen, maupun dari segi anggaran. Akan tetapi, nampak nya di tubuh partai politik sendiri belum tersosialisasikan adanya UU KI P no 14 tahun 2008. Hal ini terbukti dengan fakta di lapangan bahwa nyaris semua responden dalam penelitian ini belum mengetahui dengan persis isi UU KIP no 14/2008. J ika di kalangan pucuk pimpinan partai saja belum mengetahui isi UU KIP ini, bagaimana halnya dengan jajaran pengurus dan kader-kader lainnya?

Fakta di lapangan juga menunjukkan bahwa kata "keterbukaan" dan "transparansi" bagi banyak kalangan di partai politik masih multi interpretasi. 
Bahkan, di sebagian partai politik kata ini masih "alergi" untuk diterapkan. Budaya ketertutupan nampaknya masih menjadi budaya dominan dalam konteks perilaku berpolitik di sebagian besar partai politik. Budaya ketertutupan nampaknya masih menjadi budaya dominan dalam konteks perilaku berpolitik di sebagian besar partai politik. Padahal berdasarkan UU KIP no 14/2008 publik secara berkala berhak memeroleh informasi dari badan publik tersebut, baik diminta atau tidak, termasuk di dalamnya apa yang harus dilakukan oleh partai politik.

Strategi komunikasi politik yang dilakukan sebagian besar partai nyaris sama, yaitu melalui mesin politik partai. Hanya jenis konstituen yang berbeda menyebabkan masing-masing menggunakan metoda yang berbeda baik dalam pendekatan terhadap konstituen maupun dalam upaya melakukan pencitraan politik partai tersebut. Media massa juga digunakan oleh sebagian besar partai dalam rangka proses pencitraan partai tersebut. Hanya yang paling serius menggarap media jejaring sosial adalah PKS. Dalam hal ini PKS secara serius menggarap facebook, twitter sebagai media sosialisasi dan berkomunikasi dengan konstituen. Jika kader dari partai lain umumnya menggunakan Baligho untuk sosialisasi dan media pencitraan. Kader PKS di masa lalu agak "enggan" melakukan hal ini. Namun, seiring berjalannya waktu, personal branding, partai branding tidak lagi dapat dilakukan hanya dengan menggunakan saluran media tradisional. Sekarang kader dan kebijakan partai pun menganggap penting untuk melakukan personal branding dan partai branding melalui media massa, media jejaring sosial dan media umum lainnya.

Kesiapan (kelembagaan, Materi, SDM, Perangkat Lunak dan Perangkat Keras) Partai politik dalam menghadapi Transparansi sesuai dengan UU KIP 14/2008, tentang pemahaman tentang UU KIP, di partai GOLKAR sebagian tahu tapi sepertinya dalam implementasi keberatan. Partai Golkar selangkah lebih maju dari partai lainnya dalam hal ada website, call center, media lain, kalau web ada, bahkan memiliki majalah bulanan di tingkat pusat, serta di tingkat provinsi ada buletin. Call bagi pusat ada. Petugas yang menangani juga ada. Petugas yang kalau di pemerintahan bertugas humas, tapi di partai disebut bagian informasi dan komunikasi. Sejak dulu memang di Partai Golkar sudah ada bagian humas, sehingga ini pula yang menyebabkan partai ini secara komunikasi publik dan proses pencitraan tetap terdepan dibandingkan partai-partai lainnya.

\section{Tabel 1}

\section{Kategorisasi tentang Strategi Komunikasi Politik}

\begin{tabular}{|c|c|}
\hline Partai & Strategi Komunikasi Politik \\
\hline GOLKAR & $\begin{array}{l}\text { Menggunakan mesin partai yang sebagian besar berafiliasi kepada Ormas yang bernaung di bawah Partai } \\
\text { Golkar. }\end{array}$ \\
\hline PBB & $\begin{array}{l}\text { Menggunakan pendekatan kebutuhan ilmu pengetahuan dan keterampilan warga desa sebagai konstituen } \\
\text { dengan melakukan semacam pelatihan dan konsultasi pembangunan desa. }\end{array}$ \\
\hline PKS & $\begin{array}{l}\text { Komunikasi kemitraan (kolektif kolegial) bukan soal kepentingan politik, Strategynya: (1) UPPA (unit Pembinaan } \\
\text { dan Pengkaderan Anggota) Setiap anggota PKS dibina setiap seminggu sekali dengan kurikulum yang telah } \\
\text { ditentukan dari awal. Jadi kapasitas intelektual terbangun, moral kredibilitas dan skill personal terbangun } \\
\text { karena diadakan rutin; (2) Aktivitas dakwah menjadi tulang punggung utama strategi komunikasi politik. Pada } \\
\text { umumnya mereka sebagian besar sebagai ustad dan dulu pendekatannya terlalu pada nilai (value oriented) } \\
\text { yang disebarkan kepada masyarakat; (3) Mulai melakukan personal branding yang dianggap tabu tadinya. } \\
\text { Sekarang diperlukan dalam dunia politik. Dengan kesadaran itu teman-teman yang punya modal mulai berani } \\
\text { mengungkapkan jatidirinya, lebih atraktif karna parpol itu opini, jadi harus atraktif jadi bisa dikenal orang. }\end{array}$ \\
\hline PAN & $\begin{array}{l}\text { (1) Strategi komunikasi dalam membangun keterbukaan dengan publik, adalah merelakan diri sebagai bagian } \\
\text { dari publik, tidak bisa esklusif sehingga dari situ kita sudah memiliki kesiapan ketika publik meminta haknya } \\
\text { untuk tahu tentang kita; (2) Partai ini sebagai partai yang dilahirkan menjadi antitesa sistem orde baru yang } \\
\text { lama, sejak awal lahir dari semangat militan. }\end{array}$ \\
\hline PDIP & $\begin{array}{l}\text { PDI-P mulai merubah citra dirinya dari yang tadinya partai massa menjadi partai kader. Jika dulu PDI-P } \\
\text { merupakan partai berbasis massa. Sekarang mulai menata dirinya menjadi partai berbasis kader, sehingga } \\
\text { strategi komunikasi politik yang dilakukannya berbeda untuk saat ini. }\end{array}$ \\
\hline Demokrat & $\begin{array}{l}\text { Dengan berbagai kasus yang menimpa kader Partai Demokrat. Akan tetapi tetap optimis akan memeroleh } \\
\text { dukungan publik. Demokrat masih mengandalkan mesin partai dan kekuatan ketokohan Susilo Bambang } \\
\text { Yudhoyono. }\end{array}$ \\
\hline Hanura & $\begin{array}{l}\text { Pada } 2009 \text { sebagai partai baru, Hanura masih mengandalkan ketokohan pimpinan partai yaitu Jenderal } \\
\text { Wiranto. Sekarang Hanura dalam strategi komunikasinya lebih menonjolkan program dan pencapaian-pencapaian } \\
\text { yang sudah diraih Hanura sebagai partai yang bersih dan komitmen memberantas korupsi. }\end{array}$ \\
\hline
\end{tabular}


MIMBAR, Vol. 29, No. 2 (Desember, 2013): 123-132

\section{Tabel 2}

Transparansi Partai Politik dalam konteks keterbukaan informasi publik

\begin{tabular}{|c|c|}
\hline Partai & Transparansi \\
\hline GOLKAR & $\begin{array}{l}\text { Transparansi keuangan/ anggaran, kebijakan anggaran, sumber keuangan, penggunaan, pertanggungan } \\
\text { jawaban/ laporan diantaranya untuk masalah keuangan yang mengetahui itu sangat terbatas, seperti } \\
\text { Ketua, sekretaris, bendahara, paling yang sangat normatif uang dari jumlah kursi, kalau urusan } \\
\text { pertanggungan jawab kalau ada musda atau akhir masa jabatan, kalau yang rutin tahunan. Kalau untuk } \\
\text { transparansi masih kurang. Kendala itu masalah di transparansi, serta menyampaikan informasi utuh ke } \\
\text { publik, karena mungkin dalam mensikapi terhadap UU KIP itu masih apriori, pro kontra di dalamnya. Kendala } \\
\text { internal dan eksternal partai, pasti kendala internal sangat kuat sekali, karena banyak sekali faksi dalam } \\
\text { tubuh partai politik, jadi sangat mudah di manfaatkan pihak luar. }\end{array}$ \\
\hline PBB & Memiliki laporan keuangan yang terbuka kepada internal partai. \\
\hline PKS & $\begin{array}{l}\text { Dalam UU KI P yang dirasakan sangat krusial, menurut UU ini, kepentingan partai di internal belum waktunya, } \\
\text { Itu yang dikhawatirkan, menurut Islam, tidak semua hal perlu diekspos. Artinya, publik harus bisa mengakses } \\
\text { informasi yang ada dipemerintahan karena hakikat dari demokrasi itu adalah (1) Representasi (keterwakilan); } \\
\text { (2) Partisipasi, (bagaimana masyarakat bisa berpartisipasi). Hanya memang pada praktiknya yang berkaitan } \\
\text { dengan good governmentmenyangkut transparansi, masih ada sebagian kultur yang belum berani membuka } \\
\text { dokumen yang sebetulnya kategori publik kepada masyarakat luas. }\end{array}$ \\
\hline PAN & $\begin{array}{l}\text { Transparansi keuangan anggaran di PAN terkait UU KI P bahwa, Dari sejak awal berdiri soal keuangan, PAN } \\
\text { sudah memiliki sistem yang bisa diakses oleh siapa pun lembaga-lembaga yang ingin mengetahui } \\
\text { akuntabilitas di PAN secara administrasi keuangan, melalui sistem kebendaharan diPAN Laporan-laporan } \\
\text { resmi PAN dilaporkan ke KPU. }\end{array}$ \\
\hline Demokrat & $\begin{array}{l}\text { Meski terpuruk dengan berbagai kasus yang menimpa kader partainya. Partai Demokrat secara umum } \\
\text { mendukung transparansi terhadap publik. Artinya kebijakan kepartaian tidak ada kendala untuk publik } \\
\text { mengakses berbagai informasi baik dari segi rekruitmen maupun keuangan partai. }\end{array}$ \\
\hline Hanura & $\begin{array}{l}\text { Hanura sebagai partai yang komitmennya penuh dan partai yang pernah memeroleh predikat partai } \\
\text { terbersih karena kader partainya tidak ada yang terlibat korupsi. Tentu sepenuhnya mendukung tranparansi } \\
\text { terhadap publik. Publik berhak mengetahui dan memeroleh akses seluas-luasnya terhadap partai politik. } \\
\text { Karena Hanura pro rakyat dan mengukur segala sesuatu berdasarkan hati nurani yang terdalam. }\end{array}$ \\
\hline
\end{tabular}

Tabel 3

Strategi sosialisasi dan komunikasi dengan konstituen

\begin{tabular}{|c|c|}
\hline Partai & Strategi sosialisasi \\
\hline GOLKAR & $\begin{array}{l}\text { Menggunakan mesin partai dan ormas sebagai tukang punggung sosialisasi. Acara-acara dan hari-hari besar } \\
\text { keagamaan dijadikan ajang utk berkomunikasi dengan konstituen. }\end{array}$ \\
\hline PBB & $\begin{array}{l}\text { Menggunakan istilah "deliniasi kantong-kantong basis." Deliniasi itu bahasa planologi, katakanlah kita punya } \\
\text { area, seperti desa, ada pusat desanya, dimana ada kantong PBB, atau basis, maka basis itu sudah defend } \\
\text { sejak jaman masyumi ada. Sehingga siapapun ketuanya atau calegnya dia tidak akan berpikir dua kali dia } \\
\text { pasti akan memilih PBB. Inilah yang disebut dengan pemilih tradisional. }\end{array}$ \\
\hline PKS & $\begin{array}{l}\text { (1) Kader PKS merupakan mesin partai yang paling utama. Berlandaskan komunikasi kemitraan (kolektif } \\
\text { kolegial) bukan soal kepentingan politik. Maka semua momentum yg terjadi di masyarakat dijadikan ajang } \\
\text { sosialisasi; (2) Program-program unggulan PKS yang dipakai sebagai upaya membangun loyalitas di } \\
\text { konstituen, Program-program gubernur itu sebagian besar usulan PKS, seperti: ruang kelas baru, rumah } \\
\text { tidak layak huni, air bersih dan pemberdayaan ekonomi. }\end{array}$ \\
\hline PAN & $\begin{array}{l}\text { Cara menjalin komunikasi dengan konstituen, Kalau secara hubungan struktural organisasi, untuk pertemanan, } \\
\text { persahabatan, emosional masih. Agar tidak lost contact, membuat sekretariat (posko) penampung aspirasi } \\
\text { (jaringan pemilih) secara personal. }\end{array}$ \\
\hline PDIP & Mesin partai digunakan untuk sosialisasi. \\
\hline DEMOKRAT & $\begin{array}{l}\text { Mesin partai dan menggunakan saluran personal dan pertemuan-pertemuan warga dari mulai pengajian dan } \\
\text { bentuk pertemuan lainnya dalam rangka komunikasi dengan konstituen. }\end{array}$ \\
\hline HANURA & $\begin{array}{l}\text { Menggunakan mesin partai melalui kader Hanura. Komunikasi informal banyak dilakukan dalam berkomunikasi } \\
\text { dengan konstituen. J uga untuk melakukan sosialisasi program dan flatform politik partai Hanura. }\end{array}$ \\
\hline
\end{tabular}

sumber: hasil penelitian, 2011 
ATIE RACHMIATIE, DKK. Strategi Komunikasi Politik dan Budaya Transparansi Partai Politik

Tabel 4

Kesiapan Sarana dan Prasarana dalam konsteks pelayanan informasi publik

\begin{tabular}{|c|c|}
\hline Partai & SDM dan Sarana Prasarana \\
\hline GOLKAR & $\begin{array}{l}\text { Kesiapan (kelembagaan, Materi, SDM, Perangkat Lunak dan Perangkat Keras) Partai politik dalam menghadapi } \\
\text { Transparansi sesuai dengan UU KIP 14/2008, tentang pemahaman tentang UU KIP, sebagian tahu tapi } \\
\text { sepertinya dalam implementasi keberatan. Sudah ada website, call center, media lain, kalau web ada, } \\
\text { bahkan memiliki majalah bulanan di tingkat pusat, serta di tingkat propinsi ada buletin. Call bagi pusat ada. } \\
\text { Petugas yang menangani, petugas yang kalau di pemerintahan ya humas, tapi di partai di sebut bagian } \\
\text { informasi dan komunikasi. }\end{array}$ \\
\hline PBB & $\begin{array}{l}\text { Sudah siap dengan infrastruktur informasi, seperti web, twitter, tapi yang paling efektif adalah penjelasan } \\
\text { langsung ke desa-desa }\end{array}$ \\
\hline PKS & $\begin{array}{l}\text { Kalau teknologi yang digunakan untuk komunikasi dengan konstituen, Kalau PKS barang kali sudah maju, } \\
\text { karena telah memiliki supporting system IT, melalui media sosial, tatap muka, presentasi power point, } \\
\text { menggunakan alexsa dimana kita bisa petakan dimana pengguna internet terbanyak. Kita punya web da } \\
\text { facebook. twitter. Kalau komunikasi dengan struktur menggunakan email, sekarang pun sedang } \\
\text { mengembangkan skype agar ketika berbicara bisa face to face. }\end{array}$ \\
\hline PAN & $\begin{array}{l}\text { Mengenai kesiapan kelembagaan, SDM, perangkat lunak terkait UU KIP ialah, kalau untuk PAN relatif suport } \\
\text { terhadap UU KIP, karena itu termasuk kebutuhan publik. Harus tahu masyarakat tentang kebijakan-kebijakan } \\
\text { ini, partai pun mempunyai kepentingan untuk bisa secara transparan tampil dimata publik diapresiasi, dinilai, } \\
\text { dikoreksi. Kalau di PAN, infrastruktur sudah sangat terbuka untuk mengadaptasi kebijakan itu, tidak ada } \\
\text { yang disembunyikan oleh PAN. }\end{array}$ \\
\hline DEMOKRAT & $\begin{array}{l}\text { Kesiapan (kelembagaan, Materi, SDM, Perangkat Lunak dan Perangkat Keras) Partai politik dalam menghadapi } \\
\text { Transparansi sesuai dengan UU KI P 14/2008, tentang pemahaman tentang UU KI P. Sudah ada website, } \\
\text { call center. Publik sekarang terbuka dan berhak tahu apa yg terjadi di partai politik. }\end{array}$ \\
\hline HANURA & $\begin{array}{l}\text { Hanura sangat terbuka untuk diakses oleh publik kapan pun. Kesiapan lembaga sebagaimana partai politik } \\
\text { lain ada website yang dapat diakses publik setiap saat. }\end{array}$ \\
\hline
\end{tabular}

sumber: hasil penelitian

Bukti lainnya adalah bagaimana sosialisasi dan proses publisitas secara tidak langsung dilakukan oleh partai ini melalui salah satu media televisi yang dimiliki oleh salah seorang pimpinan partai ini. Golkar bila kita amati merupakan partai yang secara terus menerus melakukan publisitas di media massa, tidak hanya di masa Pemilu akan berlangsung, akan tetapi jauh-jauh hari sebelumnya pun partai ini paling gencar melakukan sosialisasi di media massa di samping partai Nasdem. Jika partai lain sepertinya agak "hit and run" dalam relasi dengan konstituen. PKS nampaknya menjadi partai paling giat dalam pendekatan terhadap konstituen. Berbagai kegiatan sosial kemasyarakatan kerap digunakan oleh PKS dalam rangka meraih dukungan publik.

Bentuk pertemuan dengan konstituen, seringkali dikumpulkan, sekalipun kunjungan personal ke pimpinan pesantren, pimpinan organisasi, masyarakat. Tapi yang lebih sering itu kita kumpulkumpul bisa lebih dari 100 orang, di kantor kecamatan/ kantor desa di mana camat, polsek, kepala desa dan pimpinan pesantren. Di awal, biasa ngumpul dimesjid (tempat yang berpihak ke PKS) dan sekarang bisa berkumpul di tempat netral (balai desa/kecamatan) itu bisa teratasi dengan proses komunikasi.

PKS punya satu istilah UPPA (unit Pembinaan dan Pengkaderan Anggota). Setiap anggota PKS dibina setiap seminggu sekali dengan kurikulum yang telah ditentukan dari awal. Jadi, kapasitas intelektual terbangun, moral kredibilitas dan skill personal terbangun karena diadakan rutin. Program unggulan PKS yang dipakai sebagai upaya membangun loyalitas di konstituen, program gubernur itu sebagian besar usulan PKS, seperti: ruang kelas baru, rumah tidak layak huni, air bersih dan pemberdayaan ekonomi.

\section{Strategi Komunikasi Politik kepada Konstituen}

Dalam strategi komunikasi politik di semua Partai Politik yang menjadi objek sekaligus subjek dalam penelitian ini, semua partai politik masih menggunakan saluran komunikasi tradisional seperti pengajian, pertemuan-pertemuan hari besar keagamaan, pendekatan personal, pendekatan massa. Khusus bagi Partai Golkar, Ormas yang bernaung secara loyal kepada Partai Golkar masih menjadi andalan dan tulang punggung dalam membangun komunikasi politik 
dengan konstituen. Umumnya, partai-partai Reformis seperti PKS, PBB, Hanura lebih menekankan "berjualan" program kepada konstituen ketimbang partai-partai lama seperti Golkar dan PDIP.

\section{Budaya Politik dan Budaya Komunikasi Politik}

Dalam tipe budaya politik parokial, terjadi ikatan seorang individu terhadap sebuah sistem politik tidaklah begitu kuat, baik secara kognitif maupun afektif. Di dalam tipe budaya politik ini, tidak ada peran politik yang bersifat khusus. Individu tidak mengharapkan perubahan apapun dari sistem politik. Ini diakibatkan oleh individu tidak merasa bahwa mereka adalah bagian dari sebuah bangsa secara keseluruhan. Individu hanya merasa bahwa mereka terikat dengan kekuasaan yang dekat dengannya, misalnya suku, agama, ataupun daerah.

Pada budaya politik subjek tingkatannya lebih tinggi dari parokial oleh sebab individu merasa bahwa mereka bagian dari warga suatu negara. Individu yang berbudaya politik merasa sebagai subyek yang memberi perhatian cukup atas politik akan tetapi sifatnya pasif. Mereka kerap mengikuti berita-berita politik tetapi tidak bangga atasnya, dalam arti, secara emosional mereka tidak merasa terlibat dengan negara mereka. Saat mereka tengah membicarakan masalah politik, cenderung ada perasaan tidak nyaman oleh sebab mereka tidak mempercayai orang lain begitu saja. Di ujung yang lain, saat berhadapan dengan institusi negara mereka merasa lemah dan tidak bisa berbuat apa-apa. Budaya politik subjek banyak berlangsung di negara-negara yang kuat (strong government) tetapi bercorak otoritaritarian atau totalitarian.

Sedangkan pada budaya politik partisipan, ini lebih tinggi tingkatannya. Dalam budaya politik partisipan, individu mengerti bahwa mereka adalah warga negara yang punya sejumlah hak maupun kewajiban. Misalnya, hak untuk menyatakan pendapat, memeroleh pekerjaan, penghasilan, pendidikan, dan di sisi lain kewajiban untuk, misalnya, membayar pajak. Dalam budaya politik partisipan, sering dan merasa bebas mendiskusikan masalah politik. Mereka merasa bahwa, hingga tingkatan tertentu, dapat mempengaruhi jalannya perpolitikan negara. Mereka pun merasa bebas dan mampu mendirikan organisasi politik baik untuk memprotes ataupun mendukung pemerintah. Jika tidak mendirikan organisasi politik, mereka pun banyak bergabung ke dalam organisasi sukarela baik bersifat politik maupun tidak. Saat mengikuti pemilu mereka cukup berbangga hati. Budaya politik partisipan utamanya banyak terjadi di negara-negara dengan tingkat kemakmuran dan keadilan yang cukup tinggi. J arang budaya politik partisipan terdapat di negaranegara yang masih bercorak otoritarian, totaliter, ataupun terbelakang secara ekonomi.

Jika diamati secara seksama dan dari hasil penelitian ini, nampaknya budaya politik yang terjadi di Indonesia meliputi ketiga strata budaya ini. Pada sebagian masyarakat Indonesia masih bersifat parokial, saat ketertarikan secara politik maupun ikatan secara politik tidak kuat. Akan tetapi ikatan politik mereka kuat dengan kekuasaan yang dekat dengan mereka baik secara kesukuan, keagamaan dan kedaerahan. Isu-isu politik keagamaan, kedaerahan dan kesukuan masih "kental" dalam tataran politik praktis di Indonesia. Bahkan budaya parokial ini dijadikan isu utama beberapa partai politik berbasis keagamaan. Bahkan di Aceh sudah ada partai yang mengusung isu kedaerahan seperti Partai Aceh.

Sedangkan, budaya politik subjek saat ini terjadi menimpa banyak kalangan. Sikap pasif banyak kalangan ini bukan karena tekanan politik yang membuat mereka pasif, melainkan akibat banyaknya kekecewaan masyarakat terhadap proses politik di Indonesia yang menyebabkan banyak kalangan sangat apatis terhadap politik. Ini terbukti dengan banyaknya massa mengambang dalam Pemilu Pilkada di beberapa daerah dan menurunnya tingkat partisipasi politik dalam pemilu.

Uniknya, sebagian besar masyarakat Indonesia juga telah menganut budaya politik partisipan, sering dan merasa bebas mendiskusikan masalah politik. Mereka merasa bahwa, hingga tingkatan tertentu, dapat memengaruhi jalannya perpolitikan negara. Mereka pun merasa bebas dan mampu mendirikan organisasi politik baik untuk memprotes ataupun mendukung pemerintah. Sehingga dapat dikatakan, budaya politik dan komunikasi politik di Indonesia masih terjadi dalam ketiga strata budaya ini.

\section{Budaya Transparansi dan Keterbukaan I nformasi Publik}

Budaya transparansi dan keterbukaan informasi publik di lingkungan Partai politik sendiri masih dilematis. Pada satu sisi, Partai Politik sepenuhnya menyadari akan tuntutan publik akan keterbukaan informasi dan publik berhak untuk mengetahui. Pada satu sisi, budaya organisasi partai seperti Golkar dan PKS pada batasanbatasan tertentu melakukan restriksi atas informasi yang dapat diakses publik perihal urusan kepartaian. Oleh karena itu, pada sebagian partai seperti PAN, Demokrat, PBB dan Hanura menyatakan bahwa tidak ada kendala dengan pemenuhan hak tahu publik atas berbagai hal dari 
partainya. Bahkan partai reformis seperti Hanura dan PAN menaruh sikap sangat positif dengan adanya keterbukaan informasi publik ini. Dan transparasi dalam pandangan mereka sangat diperlukan dalam kerangka membangun Indonesia yang lebih baik.

\section{Tabel 5}

\section{Budaya Transparansi dan Keterbukaan} Informasi Publik

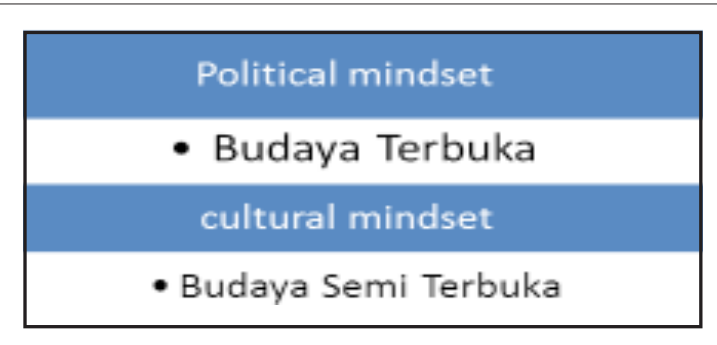

Budaya tertutup masih menjadi kendala di beberapa partai untuk membuka akses kepada publik seluas-luasnya. Budaya Politik yang masih memandang rakyat sebagai "asset" politik dan konsumen bagi "jualan" politik kalangan partai. Ini juga yang menjadi kendala bagi terbangunnya budaya terbuka dalam kerangka keterbukaan informasi kepada publik. Oleh karena itu, jikapun pihak partai politik memandang keterbukaan informasi publik menjadi sebuah keniscayaan bagi partai politik, akan tetapi pada kenyataannya masih "semi terbuka" dalam prakteknya.

\section{Simpulan dan Saran}

Budaya politik di partai politik dan konstituen sendiri masih terjadi dalam tiga strata, yaitu budaya politik parokial, subyek dan partisipan. Ini Unik mengingat lapisan-lapisan masyarakat Indonesia masih dalam strata tradisional, transisional dan segaligus sebagian sudah pada taraf demokrasi liberal dan masuk dalam kategori masyarakat modern. Strategi komunikasi politik partai pada umumnya masih bertumpu pada penggunaan saluran-saluran komunikasi tradisional seperti kumpulan pengajian dan kelompok-kelompok organisasi kemasyarakatan. Pendekatan terhadap program pemberdayaan masyarakat juga masih menjadi alat utama yang dilakukan partai politik dalam berkomunikasi dan bersosialisasi dengan konstituen.

Dalam konteks keterbukaan informasi publik, partai politik menyadari sepenuhnya tuntutan UU KIP tahun no 14 tahun 2008. Namun dalam praktiknya masih terdalam kendala-kendala internal partai dan budaya ketertutupan partai dalam hal menginformasi kan berbagai informasi partai kepada publik. Hal yang krusial adalah masalah aliran dana dan sumber dana partai politik tersebut. Oleh karena itu, partai politik ada yang sudah benar-benar terbuka dalam budaya keterbukaan informasi publik. Tetapi banyak partai yang masih dalam kategori "semi terbuka" dalam hal melayani informasi terhadap publik.

\section{Daftar pustaka}

Almond, Gabriel, A. dan Sidney, Verba (1984), Budaya politik, tingkah laku politik dan demokrasi di lima negara; Jakarta: Bina Aksara.

Applbaum, Ronald L. \& Anatol, Karl W.E. (1974). Strategies For Communication. Columbus, Ohio: Charles E. Merrill Publishing Company $\&$ A Beil \& Howell Company.

Anotasi Undang-Undang Nomor 14 Tahun 2008 tentang Keterbukaan Informasi Publik (Edisi Pertama). Jakarta: Komisi Informasi Pusat dan Indonesian Center for Environmental Law (ICEL), 2009.

Hamijoyo, S (1999). Konflik Sosial dengan Tindak Kekerasan dan Peranan Komunikasi. dalam Jurnal Mediator Volume 2 Nomor 1. Bandung

ICW. (2010) Kebebasan Informasi Milik Siapa? Jakarta.

Jean JacQues Rousseau, (1986), Kontrak Sosial Terjemahan Sumarjo, Erlangga, Jakarta

Rachmiatie, Atie., Ahmad, Sidik, Asep. dan Kamil. Farihat (2004). Peta Kesadaran Politik Para Santri di Pesantren Kabupaten Bandung Menjelang Pemilu 2004. J urnal Mimbar (Sosial dan Pembangunan) Volume XXI No. 2 April Juni 2005, hal 178-195. Penerbit P2U LPPM Unisba.

Sobur, Alex (2000), Paradigma Komunikasi Politik dalam Mewujudkan Masyarakat Madani, Jurnal MIMBAR (Sosial dan Pembangunan) Volume 16, No. 2, Tahun 2000, hal. 112-137. Penerbit P2U LPPM Unisba.

Thompson. L John, 2001, Understanding Corporate Strategy, Cengage Learning EMEA.

www.tumija Adiperwira wordpress

http://antikorupsi.org/en/content/icw-tuntutparpol-buka-pengelolaan-dana.

\section{Ucapan Terima Kasih}

Penulis mengucapkan terima kasih yang sebesarbesarnya kepada Dikti dan jajarannya serta LPPM Unisba atas dimuatnya artikel ini. dan dibiayainya penellitian ini melalui Hibah Stranas, sehingga dapat berjalan selama dua tahun. 